\title{
Natural Variation in the Arabidopsis Response to the Avirulence Gene hopPsyA Uncouples the Hypersensitive Response from Disease Resistance
}

\author{
Walter Gassmann \\ Division of Plant Sciences, University of Missouri-Columbia, Columbia, MO 65211-7310, U.S.A. \\ Submitted 18 January 2005. Accepted 9 June 2005.
}

\begin{abstract}
The plant hypersensitive response (HR) is tightly associated with gene-for-gene resistance and has been proposed to function in containing pathogens at the invasion site. This tight association has made it difficult to unequivocally evaluate the importance of $\mathrm{HR}$ for plant disease resistance. Here, hopPsyA from Pseudomonas syringae pv. syringae 61 is identified as a new avirulence gene for Arabidopsis that triggers resistance in the absence of macroscopic HR. Resistance to $P$. syringae pv. tomato $\mathrm{DC} 3000$ expressing hopPsyA was $E D S 1$-dependent and NDR1-independent. Intriguingly, several Arabidopsis accessions were resistant to DC3000(hopPsyA) in the absence of HR. This is comparable to the Arabidopsis response to avrRps4, but it is shown that hopPsyA does not signal through RPS4. In a cross between two hopPsyA-resistant accessions that differ in their HR response, the HR segregated as a recessive phenotype regulated by a single locus. This locus, HED1 (HR regulator in EDS1 pathway), is proposed to encode a protein whose activity can cause suppression of the EDS1-dependent HR signaling pathway. HED1-regulated symptomless gene-for-gene resistance responses may explain some cases of Arabidopsis resistance to bacteria that are classified as nonhost resistance.
\end{abstract}

Additional keywords: pHIR11, Pseudomonas fluorescens, P. syringae pv. glycinea, RPS6

Plant disease resistance genes govern the plant response to pathogens expressing cognate avirulence genes according to the gene-for-gene hypothesis (Flor 1971). In the absence of either the resistance gene in the plant or the avirulence gene in the pathogen, disease ensues. If both are present, the plant mounts a rapid defense response that includes an oxidative burst, ionic fluxes at the membrane, increased salicylic acid content, and induction of defense genes (Dangl and Jones 2001; Dangl et al. 1996; Hammond-Kosack and Jones 1996; Martin et al. 2003). The avirulence gene-triggered plant defense response is often accompanied by the hypersensitive response (HR), a form of localized programmed cell death that is thought to delimit pathogens to the infection site (Goodman and Novacky 1994; Greenberg and Yao 2004). Although it is generally assumed that the HR contributes to or is essential for

Corresponding author: W. Gassmann; Telephone: +1.573 .884 .7703 ; Fax: +1.573.884.9676; E-mail: gassmannw@ missouri.edu

* The $\boldsymbol{e}$-Xtra logo stands for "electronic extra" and indicates that Figures 1,2 , and 4 appear in color online and that the HTML abstract available online contains a supplemental figure not included in the print edition. resistance, it is also possible that the HR occurs as a consequence of overactive defense responses. Direct evidence for either hypothesis has been difficult to obtain, since the HR in general is tightly correlated with gene-for-gene disease resistance, and the path from pathogen recognition to cell collapse is poorly understood.

A few cases of disease resistance without HR have been described. Barley resistance to the necrotrophic leaf scald fungus Rhynchosporium secalis mediated by the Rrs 1 gene is characterized by an inhibition of hyphal growth and degradation of fungal structures in the absence of HR (Lehnackers and Knogge 1990; Rohe et al. 1995). Resistance to Potato virus X (PVX) governed by the $R x 1$ and $R x 2$ genes in potato is not accompanied by HR and is thought to be based on the extreme rapidity of the plant response. This prevents virus replication in single cells at a very early stage, thus preventing high accumulation of an HR-inducing signal (Bendahmane et al. 1999, 2000). Similar extreme resistance is observed in soybean resistance to Soybean mosaic virus (SMV), governed by the Rsvl resistance gene (Hajimorad and Hill 2001). Both PVX and SMV elicit HR on their respective hosts under certain experimental conditions, indicating that extreme resistance usually prevents macroscopic HR (Bendahmane et al. 1999; Hajimorad and Hill 2001). Interestingly, Cole and coworkers (2001) demonstrated that cell death and resistance are genetically separable in the interaction between Cauliflower mosaic virus (CaMV) and Nicotiana spp., where no extreme resistance is observed. In this system, plants that are not homozygous for the recessive cell death gene $c c d 1$ display resistance to CaMV in the absence of HR, leading to chlorotic local lesions (Cawly et al. 2005; Cole et al. 2001; Király et al. 1999). The inverse form of uncoupled HR and viral resistance was observed in the interaction between Turnip crinkle virus and Arabidopsis governed by the resistance gene $H R T$ and a putative negative regulator of disease resistance called $R R T$. In this interaction, HR can occur in the absence of resistance (Cooley et al. 2000; Kachroo et al. 2000).

Bacterial disease resistance and HR have also been genetically separated, first with the Arabidopsis dndl mutant (Clough et al. 2000; Yu et al. 1998). The dndl mutant does not mount an HR but still shows resistance to pathogens expressing the avirulence genes avrRpt2, avrB, avrRpm1, and avrRps4. This mutant also shows stunting, constitutively higher levels of salicylic acid, pathogenesis-related gene induction, and increased resistance to virulent pathogens. These characteristics are abolished in $d n d l$ mutants transformed with the bacterial $n a h G$ gene, which degrades salicylic acid and is known to counteract constitutively active defenses (Clough et al. 2000). Interestingly, the $n a h G$ transgene only partially abolished the stunted phenotype and loss of HR in dndl plants. DNDl en- 
codes a cation channel of the cyclic nucleotide gated ion channel family (Clough et al. 2000; Leng et al. 1999). Recently, a closely related cyclic nucleotide gated ion channel mutant, hlml (Balagué et al. 2003), and the allelic mutant $d n d 2$ (Jurkowski et al. 2004) were found to give similar phenotypes. The recessive $d n d 1-1$ and $d n d 2-1$ alleles and the hlml knockout allele indicate that wild-type DND1 and HLM1/DND2 function as positive regulators of HR. Although the phenotypes are somewhat pleiotropic, dnd mutants can be used to explore the general regulation of cell death activation in plants.

Among Arabidopsis accessions, variation exists in the HR response independent of the resistance response to Pseudomonas syringae pv. tomato DC3000 expressing avrRps4. Even though Col-0 is resistant to DC3000(avrRps4) as shown by reduced bacterial multiplication, it does not react with an HR. This is in contrast to Ws-0 or Po-1, which give a strong HR (Gassmann et al. 1999; Hinsch and Staskawicz 1996). Yet Col-0 is capable of giving a strong HR in response to bacteria expressing other avirulence genes. Resistance to bacteria expressing avrRps 4 in Arabidopsis is governed by RPS4, a member of the toll interleukin-1 receptor nucleotide-binding site leucine-rich repeat (TIR-NBS-LRR) class of resistance genes (Gassmann et al. 1999). Like most TIR-NBS-LRR genes, RPS4 function is fully dependent on EDS1 and not on NDRI (Aarts et al. 1998). EDS1 (Falk et al. 1999; Parker et al. 1996) and NDRl (Century et al. $1995,1997)$ are genetically downstream of resistance genes and are thought to define separate disease resistance signaling pathways (Glazebrook 2001; Hammond-Kosack and Parker 2003). Initially, it was hypothesized that the Col-0 response to avrRps 4 is a weak form of resistance dependent on the RPS4-Col allele. Consistent with this hypothesis, an RPS4-Col transgene in the susceptible accession RLD also gave resistance in the absence of HR (Gassmann et al. 1999).

In the present paper, it is shown that hopPsyA from P. syringae pv. syringae 61 is a new avirulence gene for Arabidopsis. Interestingly, Col-0 responded similarly to hopPsyA and avrRps4, in that Col-0 was resistant to DC3000 expressing hopPsyA in disease assays but gave no HR at high bacterial titer. Also, resistance to DC3000(hopPsyA) was dependent on EDS1 and independent of NDR1. Importantly, resistance to hopPsyA was not mediated by RPS4, which would have explained the similar phenotypes. By crossing Col-0 and Ws-0, two hopPsyA-resistant accessions that differ in their HR response, it was found that the HR was a recessive phenotype regulated by a single locus. It is concluded that uncoupling of $\mathrm{HR}$ and disease resistance in Col-0 is governed by a new locus, HEDI (HR regulator in EDS1 pathway), on the bottom of chromosome 5 , that is proposed to function as a negative regulator of HR in Col- 0 .

\section{RESULTS}

hopPsyA is a new avirulence gene for Arabidopsis.

In the course of studying the Col- 0 response to high titers of bacteria, the nonpathogenic bacterium Pseudomonas fluorescens 55 containing the cosmid pHIR11 was used at $10^{8}$ and $2 \times 10^{8}$ $\mathrm{CFU} / \mathrm{ml}$. Cosmid pHIR11 contains the type III secretion system genes of $P$. syringae pv. syringae 61 (Huang et al. 1988). Surprisingly, it was found that $P$. fluorescens(pHIR11) alone, without added avirulence genes, can cause a strong HR on some Arabidopsis accessions. As shown in Figure 1, Ws-0 gave a strong HR to P. fluorescens(pHIR11) inoculated at $10^{8} \mathrm{CFU} / \mathrm{ml}$, while no symptoms were seen on Col- 0 after $24 \mathrm{~h}$. Interestingly, the HR in Ws-0 was dependent on EDS1, since the edsl-1 mutant line also showed no symptoms (Fig. 1). As expected, the $n d r 1-1$ line (in Col-0 background) gave no HR (Fig. 1). Since an $n d r 1$ mutant in the Ws-0 background was not available, it was not possible to determine whether the HR response is solely reliant on EDS1 or on both EDS1 and NDRI. Interestingly, a consistent chlorosis of Col-0 and $n d r 1-1$ leaves was observed 3 to 5 days after inoculation with $P$. fluorescens(pHIR11) (data not shown). This chlorosis was not observed with eds1-1 or with pHIR11 derivatives that do not induce HR on Ws-0 (discussed below), indicating that perhaps Col-0 reacts with a form of delayed senescence rather than HR.

To determine which gene in $P$. fluorescens(pHIR11) triggers HR in Ws-0, a series of transposon-mutagenized and deletion constructs of pHIR11 (courtesy of J. Alfano, University of Nebraska-Lincoln, U.S.A.) were tested (Table 1). HR induction was abolished with pCPP2089 (data not shown), which carries a TnPhoA insertion in $h r c C$ on pHIR11 (Huang et al.
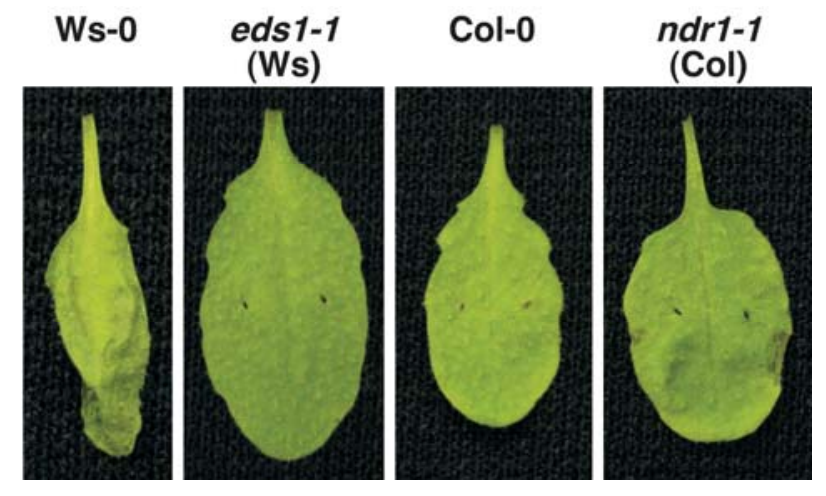

Fig. 1. EDS1-dependent hypersensitive response (HR) induced by Pseudomonas fluorescens(pHIR11) in Ws-0. Leaves of indicated Arabidopsis lines were inoculated with $P$. fluorescens(pHIR11) at $10^{8} \mathrm{CFU} / \mathrm{ml}$. HR (leaf collapse) was recorded $24 \mathrm{~h}$ after inoculation.

Table 1. Bacterial strains and plasmids

\begin{tabular}{|c|c|c|}
\hline Strain or plasmid & Relevant characteristics $^{a}$ & Reference \\
\hline \multicolumn{3}{|l|}{ Strains } \\
\hline Pseudomonas fluorescens 55 & $\mathrm{Nal}^{\mathrm{r}}$ & Huang et al. 1988 \\
\hline P. syringae pv. tomato DC3000 & Wild type, Rif ${ }^{\mathrm{r}}$ & Cuppels 1986 \\
\hline P. syringae pv. syringae race 5 & Wild type, Rif $^{\mathrm{r}}$ & Shapiro 2000 \\
\hline \multicolumn{3}{|l|}{ Plasmids } \\
\hline pHIR11 & P. syringae pv. syringae 61 hrp cluster cloned in pLAFR3, $\mathrm{Tc}^{\mathrm{r}}$ & Huang et al. 1988 \\
\hline pCPP2071 & pHIR11 derivative with $\mathrm{Tn} P h o A$ insertion in hopPsyA, $\mathrm{Tc}^{\mathrm{r}} \mathrm{Km}^{\mathrm{r}}$ & Huang et al. 1991 \\
\hline pCPP2089 & pHIR11 derivative with $\mathrm{Tn} P h o A$ insertion in $h r c C, \mathrm{Tc}^{\mathrm{r}} \mathrm{Km}^{\mathrm{r}}$ & Huang et al. 1991 \\
\hline pCPP2274 & pHIR11 derivative with precise deletion of $h r p Z$ ORF, $\mathrm{Tc}^{\mathrm{r}}$ & Gopalan et al. 1996 \\
\hline pLN18 & pHIR11 derivative with precise deletion of $s h c A-h o p P s y A$ operon, $\mathrm{Tc}^{\mathrm{r}} \mathrm{Km}^{\mathrm{r}}$ & Jamir et al. 2004 \\
\hline pML123 & Broad-host-range cloning vector, $\mathrm{Gm}^{\mathrm{r}}$ & Labes et al. 1990 \\
\hline pLN92 & pML123 derivative containing shcA and hopPsyA, $\mathrm{Gm}^{\mathrm{r}}$ & van Dijk et al. 2002 \\
\hline pVSP61 & Broad-host-range cloning vector, $\mathrm{Km}^{\mathrm{r}}$ & Hinsch and Staskawicz 1996 \\
\hline pV316-1A & pVSP61 derivative containing avrRps $4, \mathrm{Km}^{\mathrm{r}}$ & Hinsch and Staskawicz 1996 \\
\hline
\end{tabular}

${ }^{\mathrm{a}} \mathrm{Gm}=$ gentamycin, $\mathrm{Km}=$ kanamycin, $\mathrm{Nal}=$ nalidixic acid, $\mathrm{Rif}=$ rifampicin, and $\mathrm{Tc}=$ tetracycline. 
1991). The $h r c C$ gene encodes an outer membrane protein of the type III secretion machinery. The plasmid pCPP2274 has a precise deletion of the harpin $h r p Z$ gene and also abolished HR induction (data not shown). However, this did not immediately implicate $h r p Z$ as the avirulence gene, since $h r p Z$ was also found to be necessary for AvrB and AvrRpt 2 delivery from $P$. fluorescens(pHIR11) (Gopalan et al. 1996). Interestingly, a TnPhoA-insertion in hopPsyA on plasmid pCPP2071 abolished HR (Table 2). This strain still secretes harpin (Alfano et al. 1996), showing that $h r p Z$ is not the avirulence gene.

HopPsyA (formerly called HrmA) is a pHIR11-encoded effector protein that triggers HR in certain Nicotiana species (Alfano et al. 1997). The hopPsyA gene is physically linked in an operon with $s h c A$, which encodes a cochaperone that is required for HopPsyA secretion (van Dijk et al. 2002). A precise deletion of $s h c A$ and hopPsyA in plasmid pLN18 (Jamir et al. 2004) abolished HR, further suggesting that hopPsyA is the avirulence gene (Table 3). For unknown reasons, pHIR11 deletion derivatives were not complementable by the plasmid pLN92 carrying shcA-hopPsyA (Table 3).

\section{Col-0 is resistant to $\mathrm{DC} 3000(h o p P s y A)$ in disease assays.}

To prove that hopPsyA is the avirulence gene on pHIR11 recognized in Arabidopsis, pLN92 carrying shcA-hopPsyA (van Dijk et al. 2002) was introduced into DC3000. For HR assays, DC3000 strains were infiltrated into leaves at a density of $2 \times$ $10^{7} \mathrm{CFU} / \mathrm{ml}$. Consistent with hopPsyA being the avirulence gene, DC3000(hopPsyA) caused an HR on Ws-0 within $24 \mathrm{~h}$ but not on Col-0, similar to DC3000(avrRps4) (Fig. 2). Transfer of hopPsyA to DC3000 allowed the analysis of disease resistance independent of an HR phenotype. Col-0 is resistant to DC3000(avrRps4) in disease assays with low inoculum of bacteria, despite the absence of an HR phenotype at high inoculum (Gassmann et al. 1999; Hinsch and Staskawicz 1996). Similar to DC3000(avrRps4), both Ws-0 and Col-0 gave a resistant phenotype to DC3000(hopPsyA), based on the absence of chlorosis 5 days after inoculation with bacteria at $10^{6} \mathrm{CFU} / \mathrm{ml}$ (Fig. 3A).

The finding of resistance in Col-0 to DC3000(hopPsyA) allowed the testing of resistance in the $n d r l-1$ mutant line. Unlike $e d s 1-1, n d r l-1$ plants were resistant to DC3000(hopPsyA) (Fig. 3A). These results were confirmed by measuring in planta bacterial growth. As shown in Figure 3B, the resistant plants Ws-0, Col-0, and ndrl-1 showed approximately 100 to 1,000-fold less bacterial growth with DC3000(hopPsyA) than eds 1-1 plants, while virulent DC3000 grew to high levels indica-

Table 2. Hypersensitive response (HR) assays with Pseudomonas fluorescens containing pHIR 11 or pCPP2071 ${ }^{\mathrm{a}}$

\begin{tabular}{lcc}
\hline Plants & pHIR11 & pCPP2071 \\
\hline Ws-0 & $17 / 21^{\mathrm{b}}$ & $0 / 21$ \\
Col-0 & $2 / 20$ & $0 / 20$ \\
eds $1-1$ (Ws) & $0 / 21$ & $0 / 21$ \\
ndr $1-1$ (Col) & $0 / 12$ & $0 / 12$ \\
\hline
\end{tabular}

${ }^{\mathrm{a}} \mathrm{HR}$ was scored $24 \mathrm{~h}$ after inoculation with the indicated strain at a density of $10^{8} \mathrm{CFU} / \mathrm{ml}$

${ }^{\mathrm{b}}$ Numbers denote plants that were $\mathrm{HR}^{+} /$total number tested.

Table 3. Hypersensitive response (HR) assays with Pseudomonas fluorescens containing pHIR11, pLN18, or pLN18 and pLN92 ${ }^{\mathrm{a}}$

\begin{tabular}{lccc}
\hline Plants & pHIR11 & pLN18 & pLN18 + pLN92 \\
\hline Ws-0 & $11 / 11^{\mathrm{b}}$ & $0 / 11$ & $1 / 11$ \\
Col-0 & $1 / 11$ & $0 / 11$ & $0 / 11$ \\
\hline
\end{tabular}

${ }^{\mathrm{a}} \mathrm{HR}$ was scored $24 \mathrm{~h}$ after inoculation with the indicated strain at a density of $10^{8} \mathrm{CFU} / \mathrm{ml}$.

${ }^{\mathrm{b}}$ Numbers denote plants that were $\mathrm{HR}^{+} /$total number tested. tive of a susceptible interaction on all plant lines (Fig. 3B). Similar to its response to DC3000(avrRps4), Col-0 is therefore resistant to DC3000(hopPsyA) without displaying a macroscopic HR phenotype at high bacterial inoculum. Experiments to detect single-cell death using Evan's blue staining or autofluorescence did not provide evidence for an increase in single-cell death in Col-0 infiltrated with $P$. fluorescens(pHIR11) compared with the background observed with $P$. fluorescens(pLN18) (data not shown).

\section{Two Arabidopsis loci control the response to bacteria expressing hopPsyA.}

A simple explanation for the identical $\mathrm{HR}$ and resistance phenotypes observed with avrRps4 and hopPsyA would be if hopPsyA also signals through RPS4. This situation would be comparable to avrRpml and $a v r B$, both of which interact with the RPM1 resistance gene (Grant et al. 1995). To exclude this possibility, hopPsyA was tested on RLD, which has a nonfunctional allele of RPS4 (Gassmann et al. 1999; Hinsch and Staskawicz 1996), and an RPS4 knock-out line from the SAIL knock-out collection (line 519-B09) (Sessions et al. 2002), which was named rps4-1 (Kwon et al. 2004). The rps4-1 allele has a T-DNA insertion in exon 2 encoding the NBS domain and is presumed to be functionally null. As shown in Figure 3C, both RLD and rps4-1 were resistant to DC3000(hopPsyA) in disease assays. This demonstrated that hopPsyA does not signal through RPS4. It is therefore proposed that the name RPS6 be reserved for the hypothesized resistance gene responsible for hopPsyA recognition.

Thus, two unrelated avirulence genes that signal through the EDS1 pathway via different resistance genes give identical HR and disease resistance phenotypes in Col-0 and Ws- 0 . In addition, the resistant accessions Po-1 (strong HR), Ler (intermediate HR), and RLD (no HR) gave identical phenotypes to hopPsyA and avrRps4 (data not shown; in the case of avrRps4 and RLD, a transgenic line containing the RPS4-Col allele was used). Consequently, it was hypothesized that a common mechanism downstream of the resistance genes regulates the HR phenotype in response to hopPsyA and avrRps4. To under-

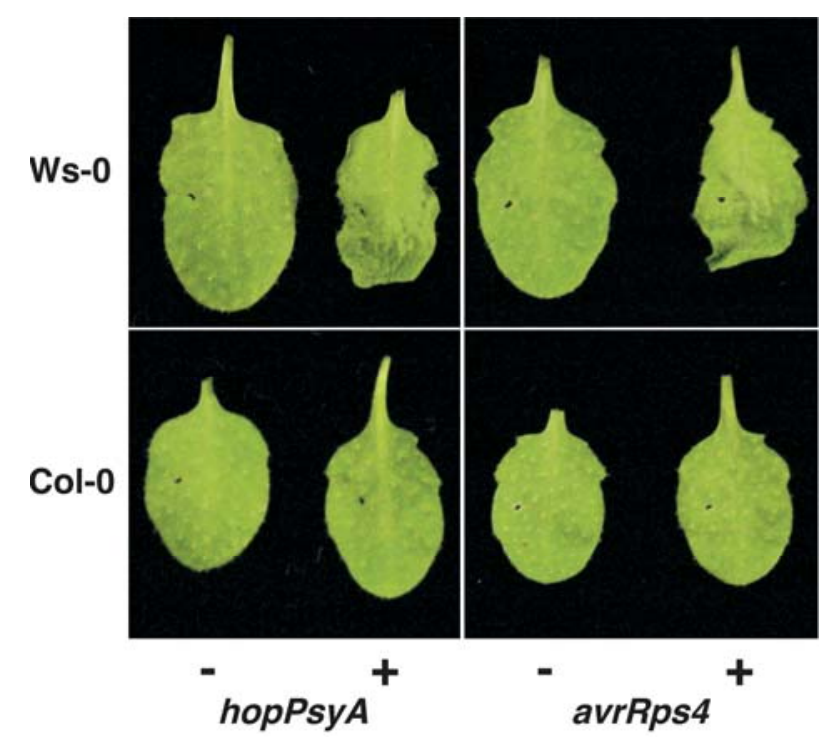

Fig. 2. hopPsyA is the avirulence gene on pHIR11 and gives phenotypes in Arabidopsis similar to avrRps4. The hypersensitive response (HR) phenotype in Ws-0 (top panels) and Col-0 (bottom panels) inoculated with DC3000 at $2 \times 10^{7} \mathrm{CFU} / \mathrm{ml}$ was recorded $24 \mathrm{~h}$ after inoculation. In the left panels, DC3000 contained either the empty vector pML123 (-), or vector pLN92 (+). In the right panels, DC3000 contained either the empty vector pVSP61 (-) or vector pV316-1A (+). 
stand the genetic basis for resistance in the absence of HR, Col-0 (resistant, $\mathrm{HR}^{-}$) was crossed with Ws-0 (resistant, $\mathrm{HR}^{+}$). F1 plants from this cross showed no HR when challenged with $P$. fluorescens(pHIR11), whereas HR segregated as a recessive phenotype conditioned by a single locus in the F2 generation (Table 4). The postulated gene at this locus was named HEDI (for HR regulator in EDS1 pathway). The recessive nature of the $\mathrm{HR}^{+}$phenotype indicated that, genetically, $H E D l$ acts as a negative regulator of HR.

A rough map position for $H E D 1$ was determined by genotyping a subset of $14 \mathrm{HR}^{+}$lines that were verified in the $\mathrm{F} 3$ generation as being homozygous $\mathrm{HR}^{+}$and, therefore, homozygous Ws0 at the HED1 locus. Based on linkage analysis, using a collection of cleaved amplified polymorphic DNA sequence (CAPS) (Konieczny and Ausubel 1993) and microsatellite (Bell and Ecker 1994) markers (Table 5), and examination of individual chromosome breakpoints, HED1 mapped to a 22-cM region on the bottom of chromosome 5 between the markers RPS4-NT and LFY3. Consistent with HEDI acting downstream of resistance genes, the three F3 lines with breakpoints between RPS4NT and LFY3 that were tested were also homozygous $\mathrm{HR}^{+}$ when inoculated with DC3000(avrRps4) (data not shown).

The results with $P$. fluorescens(pHIR11) prompted an investigation of $P$. syringae pv. glycinea race 5, since this strain was reported to be a useful nonpathogenic strain that allows observation of avrRps4-induced HR on Col-0 at high inoculum (Shapiro 2000). Interestingly, a strong HR was observed on Ws-0 with the negative control strain containing an empty vector (Figure 4). This HR was absent in eds $1-1$ plants (Figure 4). Although some loss of turgor was observed in Col-0 leaves in a few cases, the reported HR with $P$. syringae pv. glycinea race 5 (avrRps 4 ) in Col- 0 could not be replicated under these conditions (Fig. 4).

\section{DISCUSSION}

\section{HED1 as a negative regulator of $\mathrm{HR}$ in Col-0.}

Here, hopPsyA on cosmid pHIR11 from P. syringae pv. syringae 61 is identified as a new avirulence gene for Arabidopsis. Cosmid pHIR11 contains the type III secretion system genes of $P$. syringae pv. syringae 61 and allows delivery of diverse bacterial avirulence proteins from nonpathogenic bacteria such as $P$. fluorescens and Escherichia coli to plant cells for HR assays (Gopalan et al. 1996; Huang et al. 1988; Pirhonen et al. 1996). Surprisingly, it was found that $P$. fluorescens(pHIR11) alone induced a strong HR in Ws-0 while Col-0 showed no HR. Precise deletions of $s h c A-h o p P s y A$ on pHIR11 abolished the HR in Ws-0. For unknown reasons, pHIR11 deletion derivatives were not complemented by a plasmid carrying $s h c A-h o p P s y A$.

Intriguingly, Col-0 was as resistant as Ws-0 to DC3000(hopPsyA) in disease assays. Similar to avrRps4, resistance to DC3000(hopPsyA) was EDS1-dependent and NDR1independent. However, resistance to DC3000(hopPsyA) required a resistance gene other than RPS4. The absence of HR in Col-0 to hopPsyA and avrRps4 stands in contrast to the avirulence genes avrRpt2, avrB, avrRpm1, and $a v r P p h B$, which all depend on NDR1 and signal via coiled coil-NBS-LRR resistance proteins (Aarts et al. 1998) and are known to give robust HR phenotypes in Col-0. The locus controlling the HR response to hopPsyA and avrRps 4 was therefore named HEDI.

Using a small number of F3 families that were homozygous for the $\mathrm{HR}^{+}$phenotype, HEDl was mapped to the bottom of chromosome 5 between the markers RPS4-NT and LFY3. Although known disease resistance-associated genes fall within this interval, none are consistent with the phenotypes described here. RARl (Muskett et al. 2002; Tornero et al. 2002) and HSP90 (Hubert et al. 2003; Liu et al. 2004; Lu et al. 2003;
Takahashi et al. 2003) are positive regulators of disease resistance and do not have an HR-specific phenotype. The DND-type HLM1/DND2 gene is HR-specific but acts as a dominant HRactivating gene (Balagué et al. 2003; Jurkowski et al. 2004). The gene encoding AtBI1, an Arabidopsis homolog of the mammalian inhibitor of the cell death-promoting protein Bax, also is found in this interval (Sanchez et al. 2000). However, the AtBII gene is upregulated to the same extent in both incompatible and compatible interactions by nonpathogens such as E. coli and wounding and in both Col-0 and Ws- 0 . This gene induction is not dependent on either EDS1 or NDR1, and overexpression of AtBII does not compromise HR (Sanchez et al. 2000).
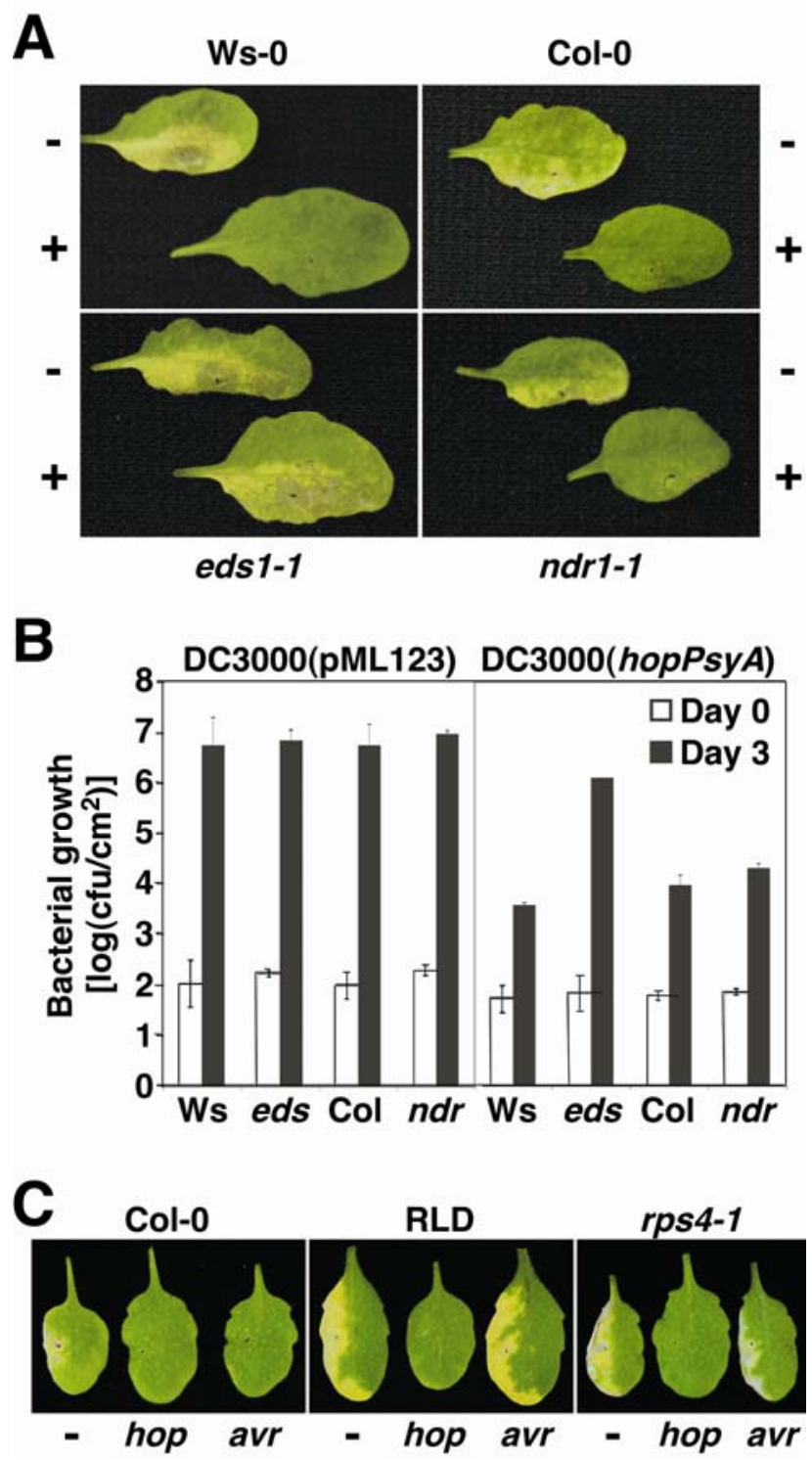

Fig. 3. Col-0 is resistant to DC3000(hopPsyA) in the absence of hypersensitive response, and resistance is independent of RPS4. A, Disease assay with DC3000 at $10^{6} \mathrm{CFU} / \mathrm{ml}$ containing either pML123 (-) or pLN92 (+) in the indicated Arabidopsis lines. Only the lower half of leaves were infiltrated, and disease (chlorosis) was scored 5 days after inoculation. B, In planta bacterial growth of DC3000(pML123) (left) and DC3000(hopPsyA) (right) in Ws-0 (Ws), eds1-1 (eds), Col-0 (Col), and $n d r 1-1$ ( $n d r)$ plants. Bacterial numbers at days 0 (open bars) and 3 (closed bars) after inoculation are shown. Error bars denote standard deviation. This experiment was repeated once with similar results. C, Disease assay with DC3000 at $10^{6} \mathrm{CFU} / \mathrm{ml}$ containing either pML123 (-), pLN92 (hop), or pV316-1A (avr). Only the left half of leaves were infiltrated, and disease (chlorosis) was scored 5 days after inoculation. 
Resistance of the avrRps4-susceptible lines RLD and rps4-1, which both carry mutations in RPS4 (Gassmann et al. 1999; Kwon et al. 2004), showed that resistance in Arabidopsis to hopPsyA required a resistance gene other than RPS4. This gene was provisionally called RPS6. A total of 32 accessions of Arabidopsis in addition to Col-0, Ws-0, Po-1, Ler, and RLD were surveyed with DC3000(hopPsyA) for resistance, to possibly identify a hopPsyA-susceptible line for map-based cloning of RPS6. However, all accessions tested were resistant to DC3000(hopPsyA). Interestingly, with these resistant accessions, there was a continuum in the HR response to $P$. fluorescens(pHIR11), from extremely rapid tissue collapse (within 6 to $7 \mathrm{~h}$ after inoculation in accession Est) to strong chlorosis in Aa-0 and very weak chlorosis in Gre-0 (data not shown). Possibly, this continuum reflects the degree to which the cell death response to hopPsyA is down-regulated by different HED1 alleles.

\section{Uncoupling of HR and disease resistance by $H E D 1$.}

The natural variation in Arabidopsis HR responses to hopPsyA developed here is an ideal genetic system that will allow important open questions regarding the function and mechanism of $\mathrm{HR}$ in disease resistance to be addressed. Mapping of HEDl was dependent on the use of P. fluorescens(pHIR11) to induce HR because $P$. fluorescens causes no disease symptoms, an approach first exemplified by the use of Arabidopsis and the bean pathogen $P$. syringae pv. phaseolicola NPS3121 (Yu et al. 1993). In contrast, HR assays with DC3000 provide only a small window of time between HR leaf collapse and collapse of susceptible leaves caused by a high titer of pathogenic bacteria. This would lead to an intolerable number of false-positives for mapping purposes.

It is important to point out that uncoupling of HR and resistance by $H E D 1$ is qualitatively different from previously described systems. The Col-0 response to hopPsyA is distinct from rapid extreme resistance, as evidenced by chlorosis of the whole inoculated leaf area 3 to 5 days after inoculation with $P$. fluorescens(pHIR11). This indicates that the response of Col-0 challenged with bacteria expressing hopPsyA or avrRps4 is actually a strongly attenuated HR that occurs in the presence of high amounts of elicitor. It is opposite from HRT/RRT (HR in absence of resistance) in that Col- 0 displays resistance in the absence of HR when challenged with hopPsyA or avrRps4. Finally, unlike in $d n d 1$ and $h l m 1 / d n d 2$ mutants, the HR ${ }^{-} /$resistance ${ }^{+}$phenotype of Col- 0 and other wild-type accessions is not accompanied by stunted growth, increased basal resistance,

Table 4. Segregation of the HR phenotype in response to hopPsyA

\begin{tabular}{|c|c|c|c|c|c|}
\hline \multirow[b]{2}{*}{ Cross $^{\mathrm{a}}$} & \multicolumn{2}{|c|}{ F1 } & \multicolumn{2}{|c|}{ F2 } & \multirow[b]{2}{*}{$\chi^{2}$} \\
\hline & $\mathrm{HR}^{+}$ & $\mathbf{H R}^{-}$ & $\mathbf{H R}^{+}$ & $\mathbf{H R}^{-}$ & \\
\hline Col- $0 \times$ Ws -0 & 0 & 10 & 46 & 156 & $0.59(P>0.3)^{\mathrm{b}}$ \\
\hline
\end{tabular}

or constitutive expression of pathogenesis-related genes. Also, DND1 and HLM1/DND2 genetically act as positive regulators of HR (Balagué et al. 2003; Clough et al. 2000; Yu et al. 1998), whereas HEDl acts as a negative regulator. HEDl-dependent uncoupling of HR and disease resistance most closely resembles the CaMV-Nicotiana spp. interaction regulated by CCD1 (Cawly et al. 2005; Cole et al. 2001; Király et al. 1999).

\section{Implications of $\mathrm{HED1}$}

for molecular plant-pathogen interactions.

The discovery of HED1-controlled symptomless gene-forgene resistance possibly has wider implications for studies in molecular plant-pathogen interactions. Efforts to identify the complete suite of effector proteins that a bacterial pathogen expresses most commonly include tests for avirulence function of each effector in Col-0, and many new avirulence genes may be missed. In fact, $P$. fluorescens(pHIR11) was previously described as failing to elicit the HR in Arabidopsis, even though hopPsyA was known to be an avirulence gene for Nicotiana spp. (Alfano et al. 1997). Based on observations with $P$. fluorescens(pHIR11) and $P$. syringae pv. glycinea race 5 , the use of other bacterial strains considered nonpathogenic on Arabidopsis may also be problematic.

The term nonhost resistance is often used to describe plant species-level resistance to all races of a given pathogen species or pathovar. This resistance appears to be the result of overlapping disease resistance mechanisms and is therefore poorly understood mechanistically (Hammond-Kosack and Parker 2003; Mysore and Ryu 2004). For bacterial pathogens and a given plant species, nonhost resistance is usually manifested by an HR at high inoculum and an absence of disease symptoms on those individuals that do not give an HR, perhaps because of missing virulence factors in the pathogen or missing susceptibility factors in the host. However, the data presented here show that absence of both HR and disease symptoms in Col-0, the reference accession for Arabidopsis, does not necessarily signify that Arabidopsis is a nonhost for a given pathogen, since the dominant avirulence genes in this pathogen may

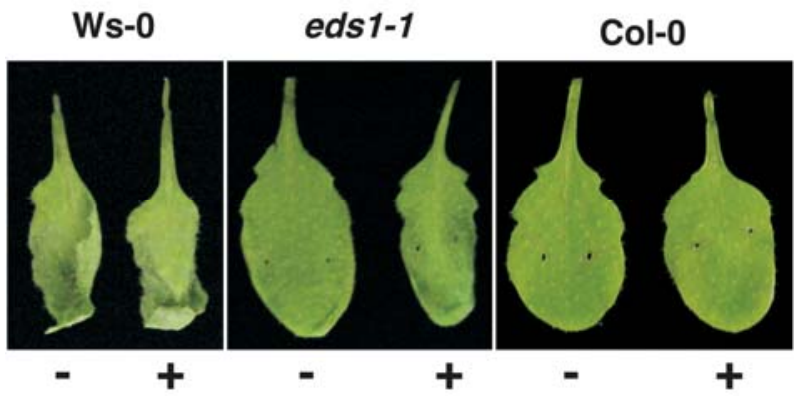

Fig. 4. EDS1-dependent hypersensitive response (HR) induced by Pseudomonas syringae pv. glycinea race 5 in Ws- 0 . The indicated Arabidopsis lines were inoculated at $1 \times 10^{9} \mathrm{CFU} / \mathrm{ml}$ with $P$. syringae $\mathrm{pv}$. glycinea race 5 containing the empty vector pVSP61 (-) or pV316-1A (+). Symptoms were recorded $24 \mathrm{~h}$ after inoculation.

Table 5. Mapping of HEDI

\begin{tabular}{lccccc}
\hline Marker $^{\mathbf{a}}$ & Position $(\mathbf{c M})$ & Recombinant chromosomes & Total number of chromosomes & Recombination frequency $(\%)$ & $\chi^{\mathbf{2}}$ \\
\hline nga151 & 30 & 15 & 28 & 54 & $0.14(P>0.7)^{\mathrm{b}}$ \\
nga139 & 50 & 11 & 28 & 39 & $1.29(P>0.2)$ \\
RPS4-NT & 95 & 3 & 28 & 11 & $17.29(P<0.001)$ \\
LFY3 & 117 & 4 & 20 & 20 & $7.20(P<0.01)$ \\
M555 & 133 & 7 & 26 & 27 & $5.54(P>0.02)$ \\
\hline
\end{tabular}

${ }^{a}$ Only markers on chromosome 5 are shown. No linkage was observed with the following markers: nga63, nga248, nga280, and ATPase on chromosome 1; GPA1.2, ER, and nga168 on chromosome 2; nga162, GAPA, and nga6 on chromosome 3; and nga8, AG, and nga1107 on chromosome 4.

${ }^{\mathrm{b}} \chi^{2}$ values are given for the expected 1:1 ratio for random segregation. 
be in the same class as hopPsyA and avrRps4. Work on HEDl may thus suggest that, even in the absence of HR, some nonhost interactions are governed by gene-for-gene interactions, as was proposed for nonhost interactions involving HR (Mysore and Ryu 2004; Whalen et al. 1988).

In the future, the cloning of $H E D l$ will enable the generation of isogenic plant lines that only differ in the ability to mount an HR. Among other things, these lines will allow a quantitative analysis of the contribution of HR to bacterial disease resistance, if any. Further, it will be possible to challenge these lines with different kinds of pathogens to determine if cell death plays a role in resistance against pathogens with different life-styles.

\section{MATERIALS AND METHODS}

\section{Plasmids and bacterial strains.}

Plasmids and bacterial strains used in this study are listed in Table 1. P. fluorescens and $P$. syringae pv. glycinea race 5 strains were grown on Difco pseudomonas agar (Becton, Dickinson and Company, Sparks, MD, U.S.A.), and DC3000 strains were grown on nutrient yeast growth medium (Daniels et al. 1984) or pseudomonas agar. Plasmids pML123 and pLN92 were mobilized into recipient DC3000, and plasmids pVSP61 and pV316-1A were mobilized into recipient $P$. fluorescens(pHIR11) from $E$. coli by triparental mating using the helper plasmid pRK2013 (Ditta et al. 1980). All other P. fluorescens strains were provided by J. Alfano, University of Nebraska-Lincoln.

\section{Plant growth and inoculations.}

Arabidopsis plants were grown in soil (Pro-Mix BX; Premier Horticulture, Inc., Quakertown, PA, U.S.A.) in a TC-30 environmental growth chamber (Conviron, Winnipeg, Canada). Temperature was set at $24^{\circ} \mathrm{C}$ and humidity at $70 \%$, with an 8 -h light and 16-h dark cycle and a photosynthetic flux of 90 to $130 \mu \mathrm{mol}$ photons $\mathrm{m}^{-2} \mathrm{~s}^{-1}$. Plants were used for experiments 4.5 to 6 weeks after planting.

Unless otherwise noted, HR assays with $P$. fluorescens strains were performed with a bacterial suspension in $10 \mathrm{mM} \mathrm{MgCl}$ with an optical density at $600 \mathrm{~nm}\left(\mathrm{OD}_{600}\right)$ of 0.1 (equivalent to 1 $\times 10^{8} \mathrm{CFU} / \mathrm{ml}$ ) and with DC3000 strains at an $\mathrm{OD}_{600}$ of 0.02 (equivalent to $2 \times 10^{7} \mathrm{CFU} / \mathrm{ml}$ ). $P$. syringae pv. glycinea race 5 strains were used at an $\mathrm{OD}_{600}$ of 1.0 (equivalent to $1 \times 10^{9}$ $\mathrm{CFU} / \mathrm{ml})$. Individual leaves were inoculated with bacterial suspensions with a needleless syringe placed over a needle hole. Inoculated plants were returned to the growth chamber. HR symptoms were recorded $24 \mathrm{~h}$ after inoculation.

For disease assays with DC3000, bacterial suspensions with an $\mathrm{OD}_{600}$ of 0.001 (equivalent to $1 \times 10^{6} \mathrm{CFU} / \mathrm{ml}$ ) were infiltrated into individual leaves as described above. Plants were returned to the growth chamber, and disease symptoms were recorded 5 days after inoculation. For in planta bacterial growth assays, leaves were infiltrated with DC3000 suspensions equivalent to $5 \times 10^{4} \mathrm{CFU} / \mathrm{ml}$. At the indicated timepoints, leaf tissue was harvested with a cork borer in triplicate, was ground in $10 \mathrm{mM} \mathrm{MgCl}_{2}$, and was plated on selective medium as described previously (Whalen et al. 1991).

\section{Arabidopsis crosses and mapping of $\mathrm{HED1}$.}

For mapping, the Col-0 and Ws-0 accessions of Arabidopsis were crossed, with Col- 0 as the female. Crosses were performed by hand-emasculating flowers before anther dehiscence and brushing donor pollen over the stigmas. Testing of F1 progeny with CAPS markers (Konieczny and Ausubel 1993) verified that they were progeny of a true cross. F1 and F2 plants were scored for $\mathrm{HR}^{+}$phenotype after syringe-inoculating with $P$. fluorescens(pHIR11). F2 plants that showed HR were selected for generation of F3 families to confirm their F2 phenotypes. DNA for analysis with microsatellite (Bell and Ecker 1994) and CAPS markers was isolated from two or three inner rosette leaves of $\mathrm{HR}^{+} \mathrm{F} 2$ plants as described previously (Gassmann et al. 1999). To identify linkage, the percentage of chromosomes derived from the Col- 0 parent at each marker was calculated. Deviation from random segregation was determined statisticcally, using the $\chi^{2}$ test with one degree of freedom.

\section{ACKNOWLEDGMENTS}

We thank J. Alfano for the generous sharing of bacterial strains and plasmids prior to their publication, D. Saha and K. Anyanwu for technical assistance, and S. Pike for critical review of the manuscript. This work was supported by University of Missouri System Research Board grant number 01-133 and in part by the Missouri Agricultural Experiment Station (project number MO-PSSL0603).

\section{LITERATURE CITED}

Aarts, N., Metz, M., Holub, E., Staskawicz, B. J., Daniels, M. J., and Parker, J. E. 1998. Different requirements for EDS1 and NDR1 by disease resistance genes define at least two $R$ gene-mediated signaling pathways in Arabidopsis. Proc. Natl. Acad. Sci. U.S.A. 95:10306-10311.

Alfano, J. R., Bauer, D. W., Milos, T. M., and Collmer, A. 1996. Analysis of the role of the Pseudomonas syringae pv. syringae HrpZ harpin in elicitation of the hypersensitive response in tobacco using functionally non-polar hrpZ deletion mutations, truncated HrpZ fragments, and hrmA mutations. Mol. Microbiol. 19:715-728.

Alfano, J. R., Kim, H.-S., Delaney, T. P., and Collmer, A. 1997. Evidence that the Pseudomonas syringae pv. syringae hrp-linked hrmA gene encodes an Avr-like protein that acts in an hrp-dependent manner within tobacco cells. Mol. Plant-Microbe Interact. 10:580-588.

Balagué, C., Lin, B. Q., Alcon, C., Flottes, G., Malmström, S., Köhler, C., Neuhaus, G., Pelletier, G., Gaymard, F., and Roby, D. 2003. HLM1, an essential signaling component in the hypersensitive response, is a member of the cyclic nucleotide-gated channel ion channel family. Plant Cell 15:365-379.

Bell, C. J., and Ecker, J. R. 1994. Assignment of 30 microsatellite loci to the linkage map of Arabidopsis. Genomics 19:137-144.

Bendahmane, A., Kanyuka, K., and Baulcombe, D. C. 1999. The Rx gene from potato controls separate virus resistance and cell death responses. Plant Cell 11:781-791.

Bendahmane, A., Querci, M., Kanyuka, K., and Baulcombe, D. C. 2000. Agrobacterium transient expression system as a tool for the isolation of disease resistance genes: Application to the $R x 2$ locus in potato. Plant $\mathrm{J}$. 21:73-81.

Cawly, J., Cole, A. B., Király, L., Qiu, W., and Schoelz, J. E. 2005. The plant gene $C C D 1$ selectively blocks cell death during the hypersensitive response to Cauliflower mosaic virus infection. Mol. Plant-Microbe Interact. 18:212-219.

Century, K. S., Holub, E. B., and Staskawicz, B. J. 1995. NDR1, a locus of Arabidopsis thaliana that is required for disease resistance to both a bacterial and a fungal pathogen. Proc. Natl. Acad. Sci. U.S.A. 92:65976601.

Century, K. S., Shapiro, A. D., Repetti, P. P., Dahlbeck, D., Holub, E., and Staskawicz, B. J. 1997. NDR1, a pathogen-induced component required for Arabidopsis disease resistance. Science 278:1963-1965.

Clough, S. J., Fengler, K. A., Yu, I. C., Lippok, B., Smith, R. K., and Bent, A. F. 2000. The Arabidopsis dndl "defense, no death" gene encodes a mutated cyclic nucleotide-gated ion channel. Proc. Natl. Acad. Sci. U.S.A. 97:9323-9328.

Cole, A. B., Király, L., Ross, K., and Schoelz, J. E. 2001. Uncoupling resistance from cell death in the hypersensitive response of Nicotiana species to Cauliflower mosaic virus infection. Mol. Plant-Microbe Interact. 14:31-41.

Cooley, M. B., Pathirana, S., Wu, H.-J., Kachroo, P., and Klessig, D. F. 2000. Members of the Arabidopsis HRT/RPPS family of resistance genes confer resistance to both viral and oomycete pathogens. Plant Cell 12:663-676.

Cuppels, D. A. 1986. Generation and characterization of Tn5 insertion mutations in Pseudomonas syringae pv. tomato. Appl. Environ. Microbiol. 51:323-327.

Dangl, J. L., Dietrich, R. A., and Richberg, M. H. 1996. Death don't have no mercy: Cell death programs in plant-microbe interactions. Plant Cell 8:1793-1807

Dangl, J. L., and Jones, J. D. G. 2001. Plant pathogens and integrated 
defence responses to infection. Nature 411:826-833.

Daniels, M. J., Barber, C. E., Turner, D. C., Cleary, W. G., and Sawczyc, M. K. 1984. Isolation of mutants of Xanthomonas campestris pv. campestris with altered pathogenicity. J. Gen. Microbiol. 130:2447-2455.

Ditta, G., Stanfield, D., Corbin, D., and Helinski, D. R. 1980. Broad host range DNA cloning system for gram-negative bacteria: Construction of a gene bank of Rhizobium meliloti. Proc. Natl. Acad. Sci. U.S.A. 77:7347-7351.

Falk, A., Feys, B. J., Frost, L. N., Jones, J. D. G., Daniels, M. J., and Parker, J. E. 1999. EDS1, an essential component of $R$ gene-mediated disease resistance in Arabidopsis has homology to eukaryotic lipases. Proc. Natl. Acad. Sci. U.S.A. 96:3292-3297.

Flor, H. H. 1971. Current status of the gene-for-gene concept. Annu. Rev. Phytopathol. 9:275-296.

Gassmann, W., Hinsch, M. E., and Staskawicz, B. J. 1999. The Arabidopsis RPS4 bacterial-resistance gene is a member of the TIR-NBS-LRR family of disease-resistance genes. Plant J. 20:265-277.

Glazebrook, J. 2001. Genes controlling expression of defense responses in Arabidopsis-2001 status. Curr. Opin. Plant Biol. 4:301-308.

Goodman, R. N., and Novacky, A. J. 1994. The Hypersensitive Reaction in Plants to Pathogens: A Resistance Phenomenon. The American Phytopathological Society Press, St. Paul, MN, U.S.A.

Gopalan, S., Bauer, D. W., Alfano, J. R., Loniello, A. O., He, S. Y., and Collmer, A. 1996. Expression of the Pseudomonas syringae avirulence protein AvrB in plant cells alleviates its dependence on the hypersensitive response and pathogenicity (Hrp) secretion system in eliciting genotype-specific hypersensitive cell death. Plant Cell 8:1095-1105.

Grant, M. R., Godiard, L., Straube, E., Ashfield, T., Lewald, J., Sattler, A., Innes, R. W., and Dangl, J. L. 1995. Structure of the Arabidopsis RPM1 gene enabling dual specificity disease resistance. Science 269:843-846.

Greenberg, J. T., and Yao, N. 2004. The role and regulation of programmed cell death in plant-pathogen interactions. Cell. Microbiol. 6:201-211.

Hajimorad, M. R., and Hill, J. H. 2001. Rsv1-mediated resistance against Soybean mosaic virus- $\mathrm{N}$ is hypersensitive response-independent at inoculation site, but has the potential to initiate a hypersensitive responselike mechanism. Mol. Plant-Microbe Interact. 14:587-598.

Hammond-Kosack, K. E., and Jones, J. D. G. 1996. Resistance genedependent plant defense responses. Plant Cell 8:1773-1791.

Hammond-Kosack, K. E., and Parker, J. E. 2003. Deciphering plant-pathogen communication: Fresh perspectives for molecular resistance breeding. Curr. Opin. Biotechnol. 14:177-193.

Hinsch, M., and Staskawicz, B. J. 1996. Identification of a new Arabidopsis disease resistance locus, RPS4, and cloning of the corresponding avirulence gene, avrRps4, from Pseudomonas syringae pv. pisi. Mol. Plant-Microbe Interact. 9:55-61.

Huang, H.-C., Hutcheson, S. W., and Collmer, A. 1991. Characterization of the hrp cluster from Pseudomonas syringae pv. syringae 61 and TnphoA tagging of genes encoding exported or membrane-spanning Hrp proteins. Mol. Plant-Microbe Interact. 4:469-476.

Huang, H. C., Schuurink, R., Denny, T. P., Atkinson, M. M., Baker, C. J., Yucel, I., Hutcheson, S. W., and Collmer, A. 1988. Molecular cloning of a Pseudomonas syringae pv. syringae gene cluster that enables Pseudomonas fluorescens to elicit the hypersensitive response in tobacco plants. J. Bacteriol. 170:4748-4756.

Hubert, D. A., Tornero, P., Belkhadir, Y., Krishna, P., Takahashi, A. Shirasu, K., and Dangl, J. L. 2003. Cytosolic HSP90 associates with and modulates the Arabidopsis RPM1 disease resistance protein. EMBO (Eur. Mol. Biol. Organ.) J. 22:5679-5689.

Jamir, Y., Guo, M., Oh, H.-S., Petnicki-Ocwieja, T., Chen, S., Tang, X. Dickman, M. B., Collmer, A., and R. Alfano, J. 2004. Identification of Pseudomonas syringae type III effectors that can suppress programmed cell death in plants and yeast. Plant J. 37:554-565.

Jurkowski, G. I., Smith, R. K., Yu, I. C., Ham, J. H., Sharma, S. B., Klessig, D. F., Fengler, K. A., and Bent, A. F. 2004. Arabidopsis DND2, a second cyclic nucleotide-gated ion channel gene for which mutation causes the "defense, no death" phenotype. Mol. Plant-Microbe Interact. 17:511-520.

Kachroo, P., Yoshioka, K., Shah, J., Dooner, H. K., and Klessig, D. F. 2000. Resistance to turnip crinkle virus in Arabidopsis is regulated by two host genes and is salicylic acid dependent but NPR1, ethylene, and jasmonate independent. Plant Cell 12:677-690.

Király, L., Cole, A. B., Bourque, J. E., and Schoelz, J. E. 1999. Systemic cell death is elicited by the interaction of a single gene in Nicotiand clevelandii and gene VI of cauliflower mosaic virus. Mol. PlantMicrobe Interact. 12:919-925.

Konieczny, A., and Ausubel, F. M. 1993. A procedure for mapping Arabidopsis mutations using co-dominant ecotype-specific PCR-based markers. Plant J. 4:403-410.
Kwon, S. I., Koczan, J. M., and Gassmann, W. 2004. Two Arabidopsis srfr (suppressor of rps4-RLD) mutants exhibit avrRps4-specific disease resistance independent of RPS4. Plant J. 40:366-375.

Labes, M., Pühler, A., and Simon, R. 1990. A new family of RSF1010derived expression and $l a c$-fusion broad-host-range vectors for gramnegative bacteria. Gene 89:37-46.

Lehnackers, H., and Knogge, W. 1990. Cytological studies on the infection of barley cultivars with known resistance genotypes by Rhynchosporium secalis. Can. J. Bot. 68:1953-1961.

Leng, Q., Mercier, R. W., Yao, W. Z., and Berkowitz, G. A. 1999. Cloning and first functional characterization of a plant cyclic nucleotide-gated cation channel. Plant Physiol. 121:753-761.

Liu, Y., Burch-Smith, T., Schiff, M., Feng, S., and Dinesh-Kumar, S. P. 2004. Molecular chaperone Hsp90 associates with resistance protein N and its signaling proteins SGT1 and Rar1 to modulate an innate immune response in plants. J. Biol. Chem. 279:2101-2108.

Lu, R., Malcuit, I., Moffett, P., Ruiz, M. T., Peart, J., Wu, A. J., Rathjen, J. P., Bendahmane, A., Day, L., and Baulcombe, D. C. 2003. High throughput virus-induced gene silencing implicates heat shock protein 90 in plant disease resistance. EMBO (Eur. Mol. Biol. Organ.) J. 22:5690-5699.

Martin, G. B., Bogdanove, A. J., and Sessa, G. 2003. Understanding the functions of plant disease resistance proteins. Annu. Rev. Plant Biol. 54:23-61.

Muskett, P. R., Kahn, K., Austin, M. J., Moisan, L. J., Sadanandom, A., Shirasu, K., Jones, J. D. G., and Parker, J. E. 2002. Arabidopsis RARl exerts rate-limiting control of $R$ gene-mediated defenses against multiple pathogens. Plant Cell 14:979-992.

Mysore, K. S., and Ryu, C. M. 2004. Nonhost resistance: How much do we know? Trends Plant Sci. 9:97-104.

Parker, J. E., Holub, E. B., Frost, L. N., Falk, A., Gunn, N. D., and Daniels, M. J. 1996. Characterization of eds1, a mutation in Arabidopsis suppressing resistance to Peronospora parasitica specified by several different RPP genes. Plant Cell 8:2033-2046.

Pirhonen, M. U., Lidell, M. C., Rowley, D. L., Lee, S. W., Jin, S., Liang, Y., Silverstone, S., Keen, N. T., and Hutcheson, S. W. 1996. Phenotypic expression of Pseudomonas syringae avr genes in E. coli is linked to the activities of the hrp-encoded secretion system. Mol. Plant-Microbe Interact. 9:252-260.

Rohe, M., Gierlich, A., Hermann, H., Hahn, M., Schmidt, B., Rosahl, S., and Knogge, W. 1995. The race-specific elicitor, NIP1, from the barley pathogen, Rhynchosporium secalis, determines avirulence on host plants of the Rrs1 resistance genotype. EMBO (Eur. Mol. Biol. Organ.) J. 14:4168-4177.

Sanchez, P., Zabala, M. D., and Grant, M. 2000. AtBI-1, a plant homologue of Bax Inhibitor-1, suppresses Bax-induced cell death in yeast and is rapidly upregulated during wounding and pathogen challenge. Plant J. 21:393-399.

Sessions, A., Burke, E., Presting, G., Aux, G., McElver, J., Patton, D. Dietrich, B., Ho, P., Bacwaden, J., Ko, C., Clarke, J. D., Cotton, D. Bullis, D., Snell, J., Miguel, T., Hutchison, D., Kimmerly, B., Mitzel, T., Katagiri, F., Glazebrook, J., Law, M., and Goff, S. A. 2002. A highthroughput Arabidopsis reverse genetics system. Plant Cell 14:2985-2994.

Shapiro, A. D. 2000. Using Arabidopsis mutants to delineate disease resistance signaling pathways. Can. J. Plant Pathol. 22:199-216.

Takahashi, A., Casais, C., Ichimura, K., and Shirasu, K. 2003. HSP90 interacts with RAR1 and SGT1 and is essential for RPS2-mediated disease resistance in Arabidopsis. Proc. Natl. Acad. Sci. U.S.A. 100:11777-11782.

Tornero, P., Merritt, P., Sadanandom, A., Shirasu, K., Innes, R. W., and Dangl, J. L. 2002. RAR1 and NDR1 contribute quantitatively to disease resistance in Arabidopsis, and their relative contributions are dependent on the $R$ gene assayed. Plant Cell 14:1005-1015.

van Dijk, K., Tam, V. C., Records, A. R., Petnicki-Ocwieja, T., and Alfano, J R. 2002. The ShcA protein is a molecular chaperone that assists in the secretion of the HopPsyA effector from the type III (Hrp) protein secretion system of Pseudomonas syringae. Mol. Microbiol. 44:1469-1481.

Whalen, M. C., Stall, R. E., and Staskawicz, B. J. 1988. Characterization of a gene from a tomato pathogen determining hypersensitive resistance in non-host species and genetic analysis of this resistance in bean. Proc. Natl. Acad. Sci. U.S.A. 85:6743-6747.

Whalen, M. C., Innes, R. W., Bent, A. F., and Staskawicz, B. J. 1991. Identification of Pseudomonas syringae pathogens of Arabidopsis and a bacterial locus determining avirulence on both Arabidopsis and soybean. Plant Cell 3:49-59.

Yu, G. L., Katagiri, F., and Ausubel, F. M. 1993. Arabidopsis mutations at the RPS2 locus result in loss of resistance to Pseudomonas syringae strains expressing the avirulence gene avrRpt2. Mol. Plant-Microbe Interact. 6:434-443

Yu, I.-C., Parker, J., and Bent, A. F. 1998. Gene-for-gene disease resistance without the hypersensitive response in Arabidopsis dnd1 mutant. Proc. Natl. Acad. Sci. U.S.A. 95:7819-7824. 